\title{
Australian Journal of

\section{Path analysis for morphological characters and grain yield of maize hybrids}

\author{
Diego Baretta ${ }^{1}$, Maicon Nardino ${ }^{1 *}$, Ivan Ricardo Carvalho ${ }^{1}$, Rafael Nornberg ${ }^{1}$, Velci Queiróz de \\ Souza $^{2}$, Valmor Antonio Konflanz ${ }^{3}$, Antonio Costa de Oliveira ${ }^{4}$ and Luciano Carlos da Maia ${ }^{4}$ \\ ${ }^{1}$ Centro de Genômica e Fitomelhoramento, UFPel, Campus Universitário, s/n, 96010-165 Capão do Leão, RS, \\ Brasil \\ ${ }^{2}$ Laboratório de Melhoramento Genético e Produção de Plantas, UFSM/FW, Linha 7 de Setembro, s/n, BR 386 \\ Km 4098400-000, Frederico Westphalen, RS, Brasil \\ ${ }^{3}$ Empresa KSP Sementes Ltda. Pato Branco, PR, 85504-050, Brasil \\ ${ }^{4}$ Professor (s) PH. D e Dr. do Departamento de Fitotecnia, área de Fitomelhoramento da Universidade Federal \\ de Pelotas, Brasil
}

*Corresponding author: barettadiego@gmail.com; nardinomn@gmail.com; carvalho.irc@gmail.com; rafaelnornberg@yahoo.com.br

\begin{abstract}
The objective of this study was to estimate the correlation coefficients of phenotypic, genotypic and environment, and their consequences direct and indirectly on the yield of maize grains considering a set of environments. The experiments were conducted in randomized complete blocks with three replications in five locations in the season of 2011/2012. A thirteen morphological characters and grain yield were evaluated. Grain yield had positive but low correlation with the characters such as height of ear $\left(r_{P}=0.24 ; r_{G}=0.26\right)$, plant height $\left(r_{P}=0.27 ; r_{G}=0.29\right)$ and ear diameter $\left(r_{P}=0.59 ; r_{G}=0.68\right)$. The prolificacy $\left(r_{P}=0.35 ; r_{G}=0.43\right)$, mass on the ear $\left(r_{P}=0.49 ; r_{G}=0.55\right)$, the grain depth $\left(r_{P}=0.39 ; r_{G}=0.43\right)$, total mass of grains per ear $\left(r_{P}=0.47 ; r_{G}=0.53\right)$ and mass of hundred grains $\left(r_{P}=0.47 ; r_{G}=0.50\right)$ showed positive but medium correlation with yield. However, the ear diameter had the positive and strong correlation with grain yield. Path analysis revealed that the simultaneous selection for ear diameter and prolificacy can be a confident alternative to increase the gains in maize, considering the available variation of grain yield in maize.
\end{abstract}

Keywords: Zea mays L., correlation coefficient, direct and indirect effects, grain yield, locations of cultivation.

\section{Introduction}

The main aim of breeding program is to obtain cultivars that exceed the pre-existing advantages. The additional advantages only become possible if the new cultivar has a series of favorable phenotypes for traits of interest. Beside to the grain yield per area some other characters are beneficial such as resistance or tolerance to pests and diseases, efficiency in nutrients and water use and even better plant architecture. Breeders should handle several characters at the same time, what makes this task a constant challenge, since most of the characters can be correlated, and often in different directions (Ramalho et al., 2012).

The character grain yield as a final product is the result of the interaction of a number of genetic factors, physiological and of environmental; and therefore, cannot be considered an isolated way (Gondim et al., 2008). The selection of productive genotypes directly, from yield components, and indirectly through adaptive characters that increase grain yield, represents an important strategy to assist the plant breeders. Estimates of the correlations have a wide use in plant breeding, mainly aiming at greater efficiency in the selection of superior genotypes. Most of times the characters of interest are difficult to select due to difficulties in measurements/identification or having low heritability. Therefore, it may be more convenient aiming for characters that have high heritability and easy measurement (Carvalho et al., 2004).
Estimates of correlations between grain yield and its components have been objective of several works in diverse cultures. Despite the usefulness of these estimates in the understanding of a complex character as grain yield, they do not define direct and indirect influences of these characteristics on productivity. In this context, Wright (1921) proposed a method termed path analysis, that allows unfold the simple correlation coefficients in their direct and indirect effects. Thus, it may have an understanding of the true relationships between variables. They are only spurious associations and/or relations of cause and effect.

Literature presents several works that use this technique by maize breeders (Carvalho et al., 2001; Barros et al., 2010; Munawar et al., 2013; Valizadeh and Bahrampour, 2013). However, such studies are still extremely important, because different population genetic structures have been considered. Given the above, the objectives of this study were to estimate the phenotypic correlation coefficients, genotypic and environments between grain yield in corn and important agronomic characteristics; unfold the estimates of the correlations in direct and indirect effects by path analysis and to indicate the best characters for indirect selection by assisting breeders in the plant selection process with the most efficient manner, considering a set of environments. 


\section{Results and Discussion}

\section{Phenotypic, genetic and environment linear correlations}

In $84.6 \%$ (66 correlation) association of characters between the genetic correlations were higher or equal than the phenotypic correlations, and $85.9 \%$ (67 correlations) of associations phenotypic and genotypic correlations were higher than the environment correlations (Table 1 and 2). Thus, it is possible to conclude that the genotypic components have greater weight in the definition of correlations than environmental components of phenotypic component (Lopes et al., 2002) and Espósito et al., 2012). According to Carvalho et al. (2004) it is well-known that environment (all external conditions) is the main cause of error that reduces precision of genetic estimation. The phenotypic variation is the result of the combined action of the genotype and the environment.

Vencovsky and Barriga (1992) reported that the correlation between visual characters in an experiment is due to phenotypic effects. The phenotypic effects come from two factors, genetic and environmental. However, in plant breeding we need association, whose nature is genetics and heritable. In this experiment, most genotypic correlation coefficients were significant at $1 \%$ and $5 \%$ by t-test, and $13.63 \%$ (11 correlations), $51.51 \%$ (40 correlations) and $34.84 \%$ (27 correlations) of pairs had magnitudes classified as strong, medium and low, respectively (Table 1 and 2).

The grain yield character has had positive correlation estimates and weak magnitude with ear height, plant height, broken and lodged plants and diameter of cob; average magnitude with prolificity, ear weight, depth of grain, grain mass and mass of a hundred grains and strong magnitude with ear diameter. These results suggest that this set of characters seem to have great importance in the selection process when it aims genotypes that have high yield.

Other studies also highlight the importance of these characters. High estimates of positive correlations between grain yield with the character of grain mass, plant height and ear height, and a negative correlation between yield and broken and lodged plants were found in six landraces of maize (Barros et al., 2010). Hallauer et al. (2010) also showed high positive correlation coefficients between depth of grain, prolificacy and ear diameter with character yield of corn grain.

Grain yield consists of a main objective of plant breeding programs. However, this character has complex character, being influenced by other factors such as grain mass, ear diameter and ear prolificacy. Therefore, the selection of promising genotypes can be made based on grain yield and also other yield components that might influence the productivity of grains (Noor et al., 2013).

The correlation coefficient was negative and low magnitude between the character broken and lodged plants and grain yield. The number of broken and lodged plants is a highly undesired character in maize breeding programs. The lodging causes the rupture of the tissue, cutting the stem vasculature and impeding the recovery of plant affects the essential morphological structure to efficiently use carbohydrates, and its translocation to the grain and the earlier occurs, the greater the loss in yield (Zanatta and Oerlecke, 1991). Likewise, when there is occurrence of lodging, the ears have less mass and some fail to be harvested mechanically, causing significant losses to producers. In addition, when the ears come in contact with the soil, there is a comprome in the quality grain.

\section{Path analysis}

If the set of characters influence the grain yield and some have correlations with each other, it can be inferred that interrelationship between these variables exists. The determined character could interfere with the grain yield by another correlated variable. The most detailed of these interrelations is given by path analysis, presented in Table 3 and 4 .

For breeding purposes, it is important to verify the highly correlated characters with the main character and the most direct effect on the favorable direction for selection. Therefore, a correlated response by indirect selection is efficient (Cruz et al., 2012). Considering the direct effects on the dependent variable grain yield, and based on the phenotypic correlation matrix, it can be observed that the character diameter of cob $(r=0.359)$ has the highest positive direct effect (Table 3 ). The ear diameter revealed high correlation value with grain yield $(\mathrm{r}=0.597)$ (Table 1$)$; thereby, demonstrating good agreement between the path coefficient and the phenotypic correlation in signal and magnitude, allowing the hypothesis of true relationship of cause and effect. This indicates that genotypes with higher grain yield may be obtained by selecting larger ear diameter. The ear diameter is in relation with the other characters, confirming results obtained by Munawar et al. (2013). Vencovsky and Barriga (1992) reported a direct selection on ear diameter will be effective in improving the dependent variable, the grain yield.

The same applies to the characters prolificacy ( $\mathrm{r}=0.334)$, mass of a hundred grains $(r=0.197)$, diameter of cob $(\mathrm{r}=0.193)$, and ear height $(\mathrm{r}=0.173)$, which has positive direct effect and agreement with the phenotypic correlation coefficients. It suggests that by isolating the indirect effects of all other explanatory variables, the increase of these characters would lead to increase in yield of maize grain. Similar results were found by Valizadeh and Bahrampour (2013), Selvaraj and Nagarajan (2011), Carvalho et al. (2001).

The character ear and grain mass have positive phenotypic correlation coefficients, but unimpressive direct effect on the main variable (grain yield), showing that indirect selection of these characters will not provide satisfactory gains. Path analysis revealed that this correlation was largely explained by the positive indirect effect by ear diameter. Therefore, the associations with ear diameter can be taken into consideration for the selection, aiming genetic gains for grain yield. Characters that show a favorable correlation, but with low direct effect, imply that the selection of truncated auxiliary variable cannot provide efficient gain in the primary variable, as in the case of mass ear and mass grain. So, the best strategy should the simultaneous selection of characters, with emphasis on those that revealed significant indirect effects (Cruz et al., 2012).

In this work, it was verified that the evaluated characters can explain $61.1 \%$ of the total variation of the variable dependent on grain yield. The coefficient of determination is restricted to that magnitude, since the grain yield character is a quantitative trait and its inheritance is influenced by a large number of genes, each contributing little effect on the phenotype, with considerable environmental variance and low broad sense heritability. For a higher level of reliability of path analysis results, the phenotypic correlation matrix between characters was tested, as the multicollinearity by the number of conditions proposed by Montgomery and Peck (1981). 
Table 1. Estimate of phenotypic correlation coefficients (above diagonal) and genotypic (lower diagonal) among 13 evaluated traits in 25 maize hybrids in five cultivation locations in the agricultural year 2010/2011. CGF/FAEM-UFPel, Pelotas, RS, 2015.

\begin{tabular}{|c|c|c|c|c|c|c|c|c|c|c|c|c|c|}
\hline Variables & ${ }^{1} \mathrm{BLP}$ & EH & $\mathrm{PH}$ & PROL & GY & ED & EL & EW & DG & MG & $\mathrm{DC}$ & $\mathrm{MC}$ & MHG \\
\hline$\overline{B L P}$ & - & $0.570^{* *}$ & $0.452^{* *}$ & $-0.430^{* * *}$ & $-0.186^{* * *}$ & $-0.134^{* * *}$ & $0.055^{\mathrm{ns}}$ & $-0.408^{k * *}$ & $0.300^{* *}$ & $-0.205^{* * *}$ & $-0.454^{* * *}$ & $-0.221^{* * *}$ & $0.059^{\text {ns }}$ \\
\hline $\mathrm{EH}$ & $0.608^{* *}$ & - & $0.828^{* *}$ & $-0.297^{* *}$ & $0.248^{* *}$ & $0.170^{* *}$ & $-0.195^{* *}$ & $0.072^{\mathrm{ns}}$ & $0.639^{* * *}$ & $0.112^{*}$ & $-0.546^{* *}$ & $-0.499^{* *}$ & $0.435^{* *}$ \\
\hline PH & $0.503^{* *}$ & $0.883^{* *}$ & - & $-0.149^{* *}$ & $0.279^{* *}$ & $0.265^{* *}$ & $-0.305^{* *}$ & $-0.045^{\mathrm{ns}}$ & $0.518^{* * *}$ & $0.082^{\text {ns }}$ & $-0.326^{* * *}$ & $-0.408^{* *}$ & $0.394^{* *}$ \\
\hline PROL & $-0.613^{* *}$ & $-0.450^{* * *}$ & $-0.295^{* *}$ & - & $0.353^{* *}$ & $0.056^{\mathrm{ns}}$ & $0.203^{* * *}$ & $0.233^{* * *}$ & $-0.333^{* * *}$ & $0.111^{*}$ & $0.418^{* *}$ & $0.280^{* * *}$ & $-0.066^{\mathrm{ns}}$ \\
\hline GY & $-0.203^{* *}$ & $0.267^{* *}$ & $0.297^{* *}$ & $0.435^{* *}$ & - & $0.597^{* *}$ & $0.035^{\mathrm{ns}}$ & $0.494^{* *}$ & $0.392^{* *}$ & $0.474^{* *}$ & $0.118^{*}$ & $-0.023^{\mathrm{ns}}$ & $0.474^{* * *}$ \\
\hline ED & $-0.155^{* *}$ & $0.174^{* *}$ & $0.302^{* *}$ & $0.061^{\mathrm{ns}}$ & $0.685^{* *}$ & - & $-0.255^{* * *}$ & $0.476^{* * *}$ & $0.523^{* *}$ & $0.401^{\text {** }}$ & $0.346^{* *}$ & $0.140^{* * *}$ & $0.432^{* *}$ \\
\hline EL & $0.077^{\text {ns }}$ & $-0.225^{* *}$ & $-0.370^{* * *}$ & $0.295^{* *}$ & $0.021^{\mathrm{ns}}$ & $-0.357^{* *}$ & - & $0.214^{* *}$ & $-0.200^{* *}$ & $0.267^{* *}$ & $-0.015^{\mathrm{ns}}$ & $0.373^{* *}$ & $0.081^{\mathrm{ns}}$ \\
\hline EW & $-0.456^{* * *}$ & $0.088^{\mathrm{ns}}$ & $-0.061^{\mathrm{ns}}$ & $0.348^{* *}$ & $0.552^{* *}$ & $0.539^{* *}$ & $0.185^{* *}$ & - & $0.173^{* *}$ & $0.662^{* *}$ & $0.249^{* *}$ & $0.268^{* *}$ & $0.429^{* * *}$ \\
\hline DG & $0.337^{* *}$ & $0.700^{* *}$ & $0.593^{* *}$ & $-0.496^{* *}$ & $0.434^{* *}$ & $0.476^{* *}$ & $-0.264^{* *}$ & $0.199^{* *}$ & - & $0.428^{* *}$ & $-0.619^{* *}$ & $-0.557^{* *}$ & $0.468^{* *}$ \\
\hline MG & $-0.223^{* *}$ & $0.123^{*}$ & $0.077^{\mathrm{ns}}$ & $0.160^{* *}$ & $0.532^{* *}$ & $0.434^{* *}$ & $0.259^{* *}$ & $0.710^{* *}$ & $0.483^{* *}$ & - & $-0.101^{\mathrm{ns}}$ & $-0.089^{\mathrm{ns}}$ & $0.432^{* *}$ \\
\hline $\mathrm{DC}$ & $-0.491^{* * *}$ & $-0.594^{* *}$ & $-0.370^{* * *}$ & $0.579^{* *}$ & $0.128^{*}$ & $0.356^{* *}$ & $-0.027^{\mathrm{ns}}$ & $0.253^{\text {** }}$ & $-0.653^{* *}$ & $-0.139^{* *}$ & - & $0.742^{* *}$ & $-0.117^{*}$ \\
\hline $\mathrm{MC}$ & $-0.234^{* *}$ & $-0.526^{* * *}$ & $-0.455^{* *}$ & $0.377^{* *}$ & $-0.028^{\mathrm{ns}}$ & $0.146^{* *}$ & $0.387^{* *}$ & $0.264^{* *}$ & $-0.610^{* * *}$ & $-0.126^{*}$ & $0.774^{* *}$ & - & $0.060^{\text {ns }}$ \\
\hline MHG & $0.063^{\mathrm{ns}}$ & $0.459^{* *}$ & $0.447^{* *}$ & $-0.088^{\mathrm{ns}}$ & $0.502^{* *}$ & $0.480^{* *}$ & $0.073^{\mathrm{ns}}$ & $0.464^{* *}$ & $0.505^{* *}$ & $0.454^{* * *}$ & $-0.123^{*}$ & $0.055^{\mathrm{ns}}$ & - \\
\hline
\end{tabular}

(ED), ear length (EL), ear weight (EW), depth grains (DG), total mass ear grains (MG), diameter of cob (DC), mass cob (MC) and mass a hundred grains (MHG).

Table 2. Estimated environmental correlation coefficients among 13 evaluated traits in 25 maize hybrids in five cultivation locations in the agricultural year 2010/2011. CGF/FAEM-UFPel, Pelotas, RS, 2015

\begin{tabular}{|c|c|c|c|c|c|c|c|c|c|c|c|c|}
\hline Variables & $\mathrm{EH}$ & $\mathrm{PH}$ & PROL & GY & ED & EL & EW & DG & MG & DC & $\mathrm{MC}$ & MHG \\
\hline BLP & $0.097^{\mathrm{ns}}$ & $0.081^{\mathrm{ns}}$ & $-0.010^{\mathrm{ns}}$ & $0.020^{\mathrm{ns}}$ & $-0.002^{\mathrm{ns}}$ & $-0.120^{*}$ & $-0.067^{\mathrm{ns}}$ & $0.004^{\mathrm{ns}}$ & $-0.060^{\mathrm{ns}}$ & $-0.009^{\mathrm{ns}}$ & $-0.015^{\mathrm{ns}}$ & $-0.014^{\mathrm{ns}}$ \\
\hline $\mathrm{EH}$ & - & $0.430^{* *}$ & $0.106^{*}$ & $0.003^{\mathrm{ns}}$ & $0.166^{* *}$ & $0.048^{\mathrm{ns}}$ & $-0.059^{\mathrm{ns}}$ & $0.113^{*}$ & $0.024^{\mathrm{ns}}$ & $0.078^{\mathrm{ns}}$ & $-0.004^{\mathrm{ns}}$ & $0.025^{\text {ns }}$ \\
\hline $\mathrm{PH}$ & & - & $0.181^{* *}$ & $0.150^{* * *}$ & $0.089^{\mathrm{ns}}$ & $0.058^{\mathrm{ns}}$ & $0.041^{\mathrm{ns}}$ & $0.078^{\mathrm{ns}}$ & $0.107^{*}$ & $0.016^{\mathrm{ns}}$ & $0.036^{\mathrm{ns}}$ & $-0.101^{\mathrm{ns}}$ \\
\hline PROL & & & - & $0.256^{* *}$ & $0.053^{\mathrm{ns}}$ & $0.016^{\mathrm{ns}}$ & $0.002^{\mathrm{ns}}$ & $0.012^{\mathrm{ns}}$ & $0.011^{\mathrm{ns}}$ & $0.061^{\mathrm{ns}}$ & $0.074^{\mathrm{ns}}$ & $-0.024^{\mathrm{ns}}$ \\
\hline GY & & & & - & $0.041^{\mathrm{ns}}$ & $0.155^{\text {** }}$ & $0.080^{\mathrm{ns}}$ & $0.043^{\mathrm{ns}}$ & $0.007^{\mathrm{ns}}$ & $-0.005^{\mathrm{ns}}$ & $0.079^{\mathrm{ns}}$ & $0.038^{\text {ns }}$ \\
\hline ED & & & & & - & $0.244^{* *}$ & $0.184^{* *}$ & $0.779^{* *}$ & $0.237^{* *}$ & $0.319^{* *}$ & $0.136^{* * *}$ & $0.103^{*}$ \\
\hline EL & & & & & & - & $0.370^{* *}$ & $0.180^{* *}$ & $0.317^{* *}$ & $0.093^{\text {ns }}$ & $0.307^{* *}$ & $0.190^{* *}$ \\
\hline EW & & & & & & & - & $0.021^{\mathrm{ns}}$ & $0.392^{* *}$ & $0.242^{* *}$ & $0.406^{* *}$ & $0.164^{* *}$ \\
\hline DG & & & & & & & & - & $0.083^{\mathrm{ns}}$ & $-0.347^{* *}$ & $-0.003^{\text {ns }}$ & $0.118^{*}$ \\
\hline MG & & & & & & & & & - & $0.224^{* *}$ & $0.366^{* * *}$ & $0.252^{* *}$ \\
\hline DC & & & & & & & & & & - & $0.207^{* *}$ & $-0.023^{\text {ns }}$ \\
\hline MC & & & & & & & & & & & - & $0.189^{* *}$ \\
\hline
\end{tabular}

$(* *)$ Significant the level of $1 \%$ probability and $(*) 5 \%$ probability and $\left(^{\mathrm{ns}}\right)$ not significant at $5 \%$ probability by $\mathrm{t}$-test. $\mathrm{n}=373$. Broken and lodged plants (BLP),
(ED), ear length (EL), ear weight (EW), depth grains (DG), total mass ear grains (MG), diameter of cob (DC), mass cob (MC) and mass a hundred grains (MHG) 
Table 3. Estimates of direct effects (diagonally bold text) and indirect (off-diagonal) based on phenotypic correlation matrix of 13 agronomic traits on grain yield per plot (kg) in 25 corn hybrids in five cultivation locations in the agricultural year 2010/2011. CGF/FAEM-UFPel, Pelotas, RS, 2015.

\begin{tabular}{|c|c|c|c|c|c|c|c|c|c|c|c|c|c|}
\hline Variables & BLP & EH & $\mathrm{PH}$ & PROL & ED & EL & EW & DG & MG & DC & MC & MHG & Total \\
\hline $\mathrm{BLP}^{1}$ & -0.098 & 0.099 & 0.001 & -0.144 & -0.048 & 0.010 & -0.020 & 0.039 & -0.005 & -0.088 & 0.058 & 0.012 & $-0.186^{* *}$ \\
\hline EH & -0.056 & 0.173 & 0.003 & -0.099 & 0.061 & -0.037 & 0.004 & 0.084 & 0.003 & -0.105 & 0.130 & 0.086 & $0.248 * *$ \\
\hline $\mathrm{PH}$ & -0.044 & 0.143 & 0.003 & -0.050 & 0.095 & -0.058 & -0.002 & 0.068 & 0.002 & -0.063 & 0.106 & 0.078 & $0.279 * *$ \\
\hline PROL & 0.042 & -0.051 & 0.000 & 0.334 & 0.020 & 0.038 & 0.012 & -0.044 & 0.003 & 0.081 & -0.073 & -0.013 & $0.353 * *$ \\
\hline ED & 0.013 & 0.029 & 0.001 & 0.019 & 0.359 & -0.048 & 0.024 & 0.069 & 0.010 & 0.067 & -0.036 & 0.085 & $0.597 * *$ \\
\hline EL & -0.005 & -0.034 & -0.001 & 0.068 & -0.092 & 0.189 & 0.011 & -0.026 & 0.007 & -0.003 & -0.097 & 0.016 & $0.035^{\mathrm{ns}}$ \\
\hline EW & 0.040 & 0.012 & 0.000 & 0.078 & 0.171 & 0.040 & 0.050 & 0.023 & 0.016 & 0.048 & -0.070 & 0.085 & $0.494 * *$ \\
\hline DG & -0.029 & 0.110 & 0.002 & -0.111 & 0.188 & -0.038 & 0.009 & 0.131 & 0.011 & -0.119 & 0.145 & 0.092 & $0.392 * *$ \\
\hline MG & 0.020 & 0.019 & 0.000 & 0.037 & 0.144 & 0.050 & 0.033 & 0.056 & 0.025 & -0.020 & 0.023 & 0.085 & $0.474 * *$ \\
\hline DC & 0.044 & -0.094 & -0.001 & 0.140 & 0.124 & -0.003 & 0.012 & -0.081 & -0.003 & 0.193 & -0.193 & -0.023 & $0.118 *$ \\
\hline MC & 0.022 & -0.086 & -0.001 & 0.093 & 0.050 & 0.071 & 0.013 & -0.073 & -0.002 & 0.143 & -0.260 & 0.012 & $-0.023^{\mathrm{ns}}$ \\
\hline MHG & -0.006 & 0.075 & 0.001 & -0.022 & 0.155 & 0.015 & 0.021 & 0.062 & 0.011 & -0.023 & -0.016 & 0.197 & $0.474 * *$ \\
\hline \multicolumn{4}{|c|}{ Coefficient of determination } & 0.611 & & & & & & & & & \\
\hline \multicolumn{4}{|c|}{ Residual effect } & 0.623 & & & & & & & & & \\
\hline \multicolumn{4}{|c|}{ Value $\mathrm{k}$} & 0.016 & & & & & & & & & \\
\hline
\end{tabular}

Table 4. Estimates of direct effects (diagonally bold text) and indirect (off-diagonal) based on genotypic correlation matrix of 13 agronomic traits on grain yield per plot (kg) in 25 corn hybrids in five cultivation locations in the agricultural year 2010/2011. CGF/FAEM-UFPel, Pelotas, RS, 2015.

\begin{tabular}{|c|c|c|c|c|c|c|c|c|c|c|c|c|c|}
\hline Variables & BLP & EH & $\mathrm{PH}$ & PROL & ED & EL & EW & DG & MG & $\mathrm{DC}$ & $\mathrm{MC}$ & MHG & Total \\
\hline $\mathrm{BLP}^{1}$ & -0.148 & 0.338 & -0.142 & -0.381 & -0.087 & 0.018 & 0.121 & 0.115 & -0.006 & -0.057 & 0.026 & 0.007 & $-0.203^{* *}$ \\
\hline EH & -0.090 & 0.555 & -0.250 & -0.279 & 0.098 & -0.052 & -0.023 & 0.239 & 0.003 & -0.069 & 0.059 & 0.049 & $0.267 * *$ \\
\hline $\mathrm{PH}$ & -0.074 & 0.490 & -0.283 & -0.183 & 0.170 & -0.085 & 0.016 & 0.202 & 0.002 & -0.043 & 0.051 & 0.047 & $0.297 * *$ \\
\hline PROL & 0.090 & -0.250 & 0.083 & 0.621 & 0.034 & 0.068 & -0.093 & -0.169 & 0.004 & 0.067 & -0.043 & -0.009 & $0.435 * *$ \\
\hline ED & 0.023 & 0.097 & -0.086 & 0.038 & 0.561 & -0.082 & -0.143 & 0.162 & 0.012 & 0.041 & -0.017 & 0.051 & $0.685^{* *}$ \\
\hline EL & -0.011 & -0.125 & 0.105 & 0.183 & -0.200 & 0.230 & -0.049 & -0.090 & 0.007 & -0.003 & -0.044 & 0.008 & $0.021^{\mathrm{ns}}$ \\
\hline EW & 0.067 & 0.049 & 0.017 & 0.216 & 0.303 & 0.042 & -0.266 & 0.068 & 0.019 & 0.029 & -0.030 & 0.049 & $0.552 * *$ \\
\hline DG & -0.050 & 0.388 & -0.168 & -0.308 & 0.267 & -0.061 & -0.053 & 0.341 & 0.013 & -0.075 & 0.069 & 0.054 & $0.434 * *$ \\
\hline MG & 0.033 & 0.068 & -0.022 & 0.099 & 0.244 & 0.059 & -0.189 & 0.165 & 0.027 & -0.016 & 0.014 & 0.048 & $0.532 * *$ \\
\hline DC & 0.073 & -0.329 & 0.105 & 0.360 & 0.200 & -0.006 & -0.067 & -0.223 & -0.004 & 0.116 & -0.087 & -0.013 & $0.128 * *$ \\
\hline $\mathrm{MC}$ & 0.035 & -0.292 & 0.129 & 0.234 & 0.082 & 0.089 & -0.070 & -0.208 & -0.003 & 0.089 & -0.113 & 0.006 & $-0.028^{\mathrm{ns}}$ \\
\hline MHG & -0.009 & 0.255 & -0.126 & -0.055 & 0.269 & 0.017 & -0.123 & 0.172 & 0.012 & -0.014 & -0.006 & 0.106 & $0.502 * *$ \\
\hline \multicolumn{4}{|c|}{ Coefficient of determination } & 0.840 & & & & & & & & & \\
\hline \multicolumn{4}{|c|}{ Residual effect } & 0.399 & & & & & & & & & \\
\hline \multicolumn{4}{|l|}{ Value $\mathrm{k}$} & 0.0487 & & & & & & & & & \\
\hline
\end{tabular}


The correlation matrix showed severe multicollinearity. To overcome this problem we used the methodology proposed by Carvalho and Cruz (1996), which applies a constant $\mathrm{k}$ diagonal matrix $X^{\prime} X$ of the ordinary least squares estimator. According to Carvalho (1995) the lowest value of $k$ should be adopted, for which most path coefficients associated with the various characters are stabilized. The $\mathrm{k}$ value of 0.016 was applied, making the results presented reliable.

For the path analysis based on genotypic correlation matrix, the coefficient of determination was equal to 0.840 , characterizing $84 \%$ of the total variation. It is explained by the set of variables used in the causal diagram (Table 3). The diagnosis of multicollinearity obtained from the choice of $\mathrm{k}$ coefficient of 0.0487 allowed the correction of distortions, allowing greater reliability in the interpretation of cause and effect between the studied characters.

The magnitudes of the direct effects of the characters analyzed for the grain yield were lower than the magnitudes of the estimates of genetic correlation coefficients with that character, except for prolificacy and ear height (Table 4). Thus, it is observed that there are other characters influencing both the magnitude and the direction of the associations with the character grain yield.

The prolificacy character had the highest direct effect on grain yield $(\mathrm{r}=0.621)$ (Table 4$)$. This result agrees with the results obtained by Carvalho et al. (2001). This result allowed us to infer that genotypes with higher grain yields can be obtained by selection of prolific plants. Most prolific plants are generally more tolerant to adverse conditions. They produce an ear of corn under stress conditions and over an ear in appropriate conditions with densities below the optimum for culture. Thus, prolific hybrid has a wide range of plant density to maximize grain yield, opposed to not-prolific hybrids that have a more restrictive optimum range (Sangoi et al., 2010).

Between pairs of characters, ear diameter and grain yield showed the highest estimate of positive correlation $(r=0.685)$ and positive direct effect $(\mathrm{r}=0.561)$. Consequently, applying indirect selection for increasing the ear diameter have increased grain yield. According to Homayoun (2011), the increase in ear diameter causes an increase in the number of rows and consequently grains per ear, which contributes to grain yield in maize.

Genetic correlation between grain mass and grain yield was relatively high and positive $(\mathrm{r}=0.532)$. However, the direct effect on the dependent variable was unimpressive $(r=0.027)$. In this case, the positive indirect effects, such as character ear diameter $(r=0.244)$ and depth of grain $(r=0.165)$ and the negative indirect effect via ear mass $(r=-0.189)$, contributed to the evidenced correlation between this pair of characters. Thus, the selection of auxiliary characters did not provide satisfactory gain in the dependent variable. Therefore, the more coherent strategy is the simultaneous selection of characters, with the emphasis on characters whose indirect effects are significant as ear diameter and depth of grain. Some heritability estimates, such as depth of grain and ear diameter, twice as high to grain yield have been reported, revealing efficiency in these characters via indirect selection to increase in crop yield (Hallauer et al., 2010).

The ear mass character presented a high positive genotypic correlation value of with grain yield. It was offset by the positive indirect effect through ear diameter $(r=0.303)$, and along with the positive indirect effect through prolificacy $(\mathrm{r}=0.216)$, which resulted in positive estimate of genotypic correlation coefficient $(\mathrm{r}=0.552)$. This is justified by the fact that a larger ear mass may be associated with a higher cob contribution, as shown by the positive and significant correlation between mass cob and ear. Thus, breeders who interested in increasing the grain yield more efficiently should focus on the selection pressure on the characters diameter ear and prolificacy. According to Vencovsky and Barriga (1992), if a correlation coefficient is positive but with the negative path direct effect, it can be said that correlation has been caused by their indirect effects; therefore, both to be considered in the selection process.

The ear height character reveals positive and significant correlation with grain yield $(\mathrm{r}=0.267)$, and the total of correlation value was derived from the high direct effect $(\mathrm{r}=0.555)$. According to Vencovsky and Barriga (1992), these correlations explain the true association between these pairs of characters. However, caution is needed in selecting plants with more ear height, since the reduction of plant height and height of ear insertion are important in maize, enabling more efficient use of nitrogen. Moreover, plants have center of gravity stayed more balanced, reducing lodging and breakage of stems and favoring translocation of nutrients to crop production (Sangoi et al., 2002). The current maize hybrids are not cultivated at low densities. Among various characteristics has been improved to allow such management, the ability to support the increased plant density without elevation stature is the fundamental.

The character mass of a hundred grains has had a positive direct effect on the variable basic grain yield $(r=0.106)$. However, the negative indirect effects of plant height ( $r=-$ $0.126)$ and ear mass $(r=-0.123)$, which together have the positive indirect effects via ear diameter $(r=0.269)$ and depth of grain $(r=0.172)$, resulted in positive estimate of genotypic correlation coefficient $(\mathrm{r}=0.502)$. Thus, the plant breeders engaged on grain yield should increase the selection of the mass of one hundred grains, but should not ignore the remaining characters with significant indirect effects. The path analysis demonstrated direct effect of the grain mass on the basic variable, grain yield (Valizadeh and Bahrampour, 2013), revealing that the direct effect of this character is a good predictor of genotype correlation, highlighting the possibility of selection through this component of genetic gain with culture.

\section{Materials and Methods}

\section{Plant materials}

The hybrids were obtained at the company's research station KSP Seeds LTDA, in the city of Clevelândia-PR in the agricultural year 2010/2011. For the study we used 15 inbred lines of high grain yield as female parents, eight inbred lines with rustic features as the male parents. To obtain the hybrid we used a partial diallel, resulting in 25 hybrid combinations.

\section{Experimental design and experimental procedure}

The experiments were conducted in randomized complete blocks with three replications. Sowing of the trials was conducted in 2011/2012 agricultural harvest year at five different locations in three states of southern Brazil. In Rio Grande do Sul, the test was conducted in the City of Frederico Westphalen-RS $\left(27^{\circ} 23^{\prime} 47^{\prime \prime} \mathrm{S}, 5^{\circ} 25^{\prime} 35^{\prime \prime} \mathrm{O}, 480 \mathrm{~m}\right)$; in Santa Catarina, in the city of Itapiranga-SC $\left(27^{\circ} 10^{\prime} 10^{\prime \prime} S\right.$, $53^{\circ} 42^{\prime} 44^{\prime \prime} \mathrm{O}, 206 \mathrm{~m}$ ); in Paraná, the trials were conducted in three locations: Pato Branco-PR $\left(26^{\circ} 13^{\prime} 44^{\prime \prime} \mathrm{S}, 52^{\circ} 40^{\prime} 15^{\prime \prime} \mathrm{O}\right.$, $760 \mathrm{~m})$, Ampére-PR $\left(25^{\circ} 54^{\prime} 20^{\prime \prime} \mathrm{S}, 5^{\circ} 25^{\prime} 54^{\prime \prime} \mathrm{O}, 718 \mathrm{~m}\right)$ and Clevelândia-PR (26²1'17"S, 52²8'56" O, 860 m).

The experimental units were composed of two lines each five meters in length, spaced with 0.70 meters. The sowing 
time was carried out according to the agro climatic zoning of each local. After emergence and crop establishment the hand thinning implemented to stand adjustment of 42 plants per plot, equivalent to 60,000 plants $\mathrm{ha}^{-1}$. Soil management and cultural practices were the same for the five sites, following the phenological stages and the need for culture.

\section{Traits measured}

The following characteristics were measured: grain yield per plot (GY, in kg), broken and lodged plants (BLP, units), plant height $(\mathrm{PH}, \mathrm{m})$, ear height $(\mathrm{EH}, \mathrm{m})$, prolificacy (PROL, units), ear diameter (ED, mm), ear length $(\mathrm{EL}, \mathrm{cm})$, ear weight (EW, g), diameter of cob (DC, mm), depth of grains (DG, mm), total mass of ear grains (MG, g), mass cob (MC, $\mathrm{g}$ ) and mass of hundred grains (MHG, g).

\section{Statistical analysis}

The correlation coefficients were decomposed of: phenotypic $\left(r_{\mathrm{P}}\right)$, genetic $\left(\mathrm{r}_{\mathrm{G}}\right)$ and of environmental $\left(\mathrm{r}_{\mathrm{E}}\right)$ correlation (Hazel, 1943). Covariance components for each pair of variables ( $\mathrm{x}$ and $\mathrm{y}$ ) were obtained by the product of average genotype variations sources $(\mathrm{L})$ and residue $(\mathrm{E})$ through $\mathrm{PM}_{x y}$ $=\left[\left(\mathrm{MS}_{x+y}-\mathrm{MS}_{x}-\mathrm{MS}_{y}\right) / 2\right]$, equivalent a $\operatorname{cov}_{x y}=\left[\left(\sigma_{\mathrm{x}+\mathrm{y}}-\sigma_{\mathrm{x}}-\sigma_{\mathrm{y}}\right) / 2\right]$ and estimators: $\widehat{\sigma}_{\mathrm{xy}}^{2}=\left[\left(\mathrm{PM}_{\mathrm{G}}-\mathrm{PM}_{\mathrm{E}}\right) / \mathrm{r}\right], \widehat{\sigma}_{\mathrm{x}}^{2}=\left[\left(\mathrm{MS}_{\mathrm{G} x}-\mathrm{PM}_{\mathrm{Ex}}\right) / \mathrm{r}\right]$ and $\hat{\sigma}_{\mathrm{y}}^{2}=\left[\left(\mathrm{MS}_{\mathrm{G} y}-\mathrm{PM}_{\mathrm{Ey}}\right) / \mathrm{r}\right]$ obtained from MS genotype $(\mathrm{G})$ and residue (E) to the variables $\mathrm{x}, \mathrm{y}$ ANOVA table, resulting in phenotypic correlation, $\mathrm{r}_{\mathrm{P}}=\left[\mathrm{PM}_{\mathrm{G} x y} /\left(\mathrm{MS}_{\mathrm{G} x} \times \mathrm{MS}_{\mathrm{Gy}}\right)^{1 / 2}\right]$, environment correlation, $r_{E}=\left[\mathrm{PM}_{\mathrm{E} x y} /\left(\mathrm{MS}_{\mathrm{E} x} \times \mathrm{MS}_{\mathrm{E} y}\right)^{1 / 2}\right]$ and genetic correlation, $\mathrm{r}_{\mathrm{G}}=\left[\hat{\sigma}_{\mathrm{xy}}^{2} /\left(\hat{\sigma}_{\mathrm{x}}^{2} \times \hat{\sigma}_{\mathrm{y}}^{2}\right)^{1 / 2}\right]$, as described by Robinson \& Mode (1959). The significance of the correlations were evaluated by t-test $\mathrm{p}<0.05$ and $\mathrm{p}<0.01$, as described by Stell and Torrie (1980). The split of correlations in direct and indirect effects of important agronomic characteristics was performed (independent variables of the regression model) on the character grain yield per plot (dependent variable) through the path analysis (Wright, 1921). The degree of multicollinearity the matrix $\mathrm{X}^{\prime} \mathrm{X}$ was established based on their condition number $(\mathrm{CN})$, which is the ratio between the largest and the smallest eigenvalue in the matrix (Montgomery and Peck, 1981). To alleviate the impact of multicollinearity, if are present, the system of normal equations was modified by adding a constant $\mathrm{k}$ to the diagonal values of the matrix according to Hoerl and Kennard (1970a, 1970b). The setting of k value, for which most of the path coefficients has stabilized, is recommended.

The magnitudes of the correlation coefficients were classified as Carvalho et al. (2004): $\mathrm{r}=0$ (null); $0<|\mathrm{r}| \leq 0.30$ (weak); $0.30<|\mathrm{r}| \leq 0.60$ (average); $0.60<|\mathrm{r}| \leq 0.90$ (strong); $0.90<|\mathrm{r}| \leq 1$ (very strong) and $|\mathrm{r}|=1$ (perfect). All analyses were performed using the statistical computing app Genes (Cruz, 2013).

\section{Conclusion}

Correlation estimates and path analysis to matrices phenotypic and genotypic correlation revealed that the ear diameter and prolificacy in plants were responsible for variation of grain yield. They had the largest direct effects of favorable sense, being the characters of greater potentiality for selection of superior genotypes in maize. The low correlation between the estimates of simple association and direct effect between the character, the ear mass, depth of grain, grain mass and mass of one hundred grains did not provide efficient subsidies for the use of genetic and phenotypic correlations in identifying associations of heritable of great interest.

\section{Acknowledgements}

The authors thank the Higher Education Personnel Improvement Coordination (CAPES) for project financing and the granting of the first author's doctoral fellowship, and the company KSP Seeds Ltda., For providing the bank of inbred lines used in this study.

\section{References}

Barros LB, Moreira RMP, Ferreira JM (2010) Phenotypic, additive genetic and environment correlations of maize landraces populations in family farm systems. Sci Agric. 67: 685-691.

Carvalho FIF de, Lorencetti C, Benin G (2004) Estimativas e implicações da correlação no melhoramento vegetal. Pelotas: Ed. Universitária da UFPel 142p.

Carvalho CGP de, Borsato R, Cruz CD, Viana JMS (2001) Path analysis under multicollinearity in S0xS0 maize hybrids. Crop Breed and Appl Biot. 1: 263-270.

Carvalho SP, Cruz CD (1996) Diagnosis of multicollinearity: assessment of the condition of correlation matrices used in genetic studies. Genet Mol Res. 19: 479-484.

Carvalho SP (1995) Métodos alternativos de estimação de coeficientes de trilha e índices de seleção, sob multicolinearidade. Viçosa: UFV 163p.

Cruz CD (2013) Genes - a software package for analysis in experimental statistics and quantitative genetics. Acta Sci Agronomy. 35: 271-276.

Cruz CD, Regazzi AJ, Carneiro PCS (2012) Modelos biométricos aplicados ao melhoramento genético. $4^{\mathrm{a}}$ ed.Viçosa: UFV 514p.

Espósito DP, PeternelliI LA, Paula TOM, Barbosa MHP (2012) Análise de trilha usando valores fenotípicos e genotípicos para componentes do rendimento na seleção de famílias de cana-de-açúcar. Cienc Rural. 42: 38-44.

Gondim TCO, Rocha VS, Sediyama CS, Miranda GV (2008) Análise de trilha para componentes do rendimento e caracteres agronômicos de trigo sob desfolha. Pesqui Agropecu Bras. 43: 487-493.

Hallauer AR, Carena MJ, Miranda Filho JB de (2010) Quantitative genetics in maize breeding. Springer 663p.

Hazel LN (1943) The genetic basis for constructing selection indexes. Genetics 28: 476-90.

Hoerl AE, Kennard RW (1970a) Ridge regression: applications to nonorthogonal problems. Technometrics, Washington. 12: 69-82.

Hoerl AE, Kennard RW (1970b) Ridge regression: biased estimation for nonorthogonal problems. Technometrics, Washington. 12: 55-67.

Homayoun H (2011) Study of some morphological traits of corn hybrids. J Agr Environ Sci. 10: 810-813.

Lopes AÂC, Vello NA, Pandini F, Moura M (2002) Variabilidade e correlações entre caracteres em cruzamentos de soja. Sci Agr. 59: 341-348.

Mode CJ, Robinson HF (1959) Pleiotropism and the genetic variance and covariance. Biometrics. 15: 518-537.

Montgomery DC, Peck EA (1981) Introduction to linear regression analysis. New York : John Wiley 504p.

Munawar M, Shahbaz M, Hammada G, Yasir M (2013) Correlation and path analysis of grain yield components in exotic maize (Zea mays L.) hybrids. Internat J Scien: Basic Appl Res. 12: 22-27. 
Noor M, Durrishahwar H, Ullah H, Ali F, Iqbal M, Shah IA, Ullah I (2013) Change in heritability estimates due to halfsib family selection in the maize variety Pahari. Genet Mol Res. 12: 1872-1881.

Ramalho M, Santos JB, Pinto CB, Souza EA, Gonçalves FMA, Souza JC (2012) Genética na agropecuária. 5ed. Lavras: Ufla 565p.

Sangoi L, Almeida MD, Silva PD, Argenta G (2002) Bases morfofisiológicas para maior tolerância dos híbridos modernos de milho a altas densidades de plantas. Bragantia. 61: 101-110.

Sangoi L, Schweitzer C, Schmitt A, Pícoli Jr GJ, Vargas VP, Vieira J, Seiga E, Carniel G (2010) Perfilhamento e prolificidade como características estabilizadoras do rendimento de grãos do milho em diferentes densidades. Revista Brasileira de Milho e Sorgo. 9: 254-265.

Selvaraj CI, Nagarajan P (2011) Interrelationship and pathcoefficient studies for qualitative traits, grain yield and other yield attributes among maize (Zea mays L.). Inter J of Plant Breed Genet. 5: 209-223.
Steel RGD, Torrie JH (1980) Analysis of covariance. Principles and procedures of statistics: A Biometrical Appr. 401-437.

Valizadeh H, Bahrampour T (2013) Analysis of correlation coefficients between grain yield and its components in average and late-rripening hybrids of grain maize (Zea mays L.) Intern J Agr and Plant Prod. 4: 3377-3383.

Vencovsky R, Barriga P (1992) Genética biométrica no fitomelhoramento. Ribeirão Preto: Rev Bras Genet. 496p.

Wright S (1921) Correlation and causation. J Agric Res. 20: 557-585.

Zanatta ACA, Oerlecke D (1991) Efeito de genes de nanismo sobre alguns caracteres agronômicos e morfológicos de Triticum aestivum (L.) Thell. Pesqui Agropecu Bras. 26: 1001-1016. 